\title{
A possible case of sporadic aurora observed at Rio de Janeiro
}

\author{
Denny M. Oliveira ${ }^{1,2^{*}} \mathbb{D}$, Hisashi Hayakawa ${ }^{3,4,5}$, Ankush Bhaskar ${ }^{2,6}$, Eftyhia Zesta ${ }^{2}$ and Geeta Vichare ${ }^{7}$
}

\begin{abstract}
Being footprints of major magnetic storms and hence major solar eruptions, mid- to low-latitude aurorae have been one of the pathways to understand solar-terrestrial environments. However, it has been reported that aurorae are also occasionally observed at low latitudes under low or even quiet magnetic conditions. Such phenomena are known as "sporadic aurorae". We report on a historical event observed by a scientist of the Brazilian Empire in Rio de Janeiro on 15 February 1875. We analyze this event on the basis of its spectroscopic observations, along with its visual structure and coloration, to suggest this event was a possible case of sporadic aurorae. Given the absence of worldwide aurora observations on that day as a consequence of low magnetic activity recorded on the days preceding the observation, in addition to a detailed description, the event observed can most likely be classified as a sporadic aurora. We discuss the geographic and magnetic conditions of that event. Thus, we add a possible case of sporadic aurora in the South American sector.
\end{abstract}

Keywords: Space weather, Sporadic aurora, Analysis of historical data

\section{Introduction}

Extreme space weather events, such as the events of August-September 1859 (Carrington 1859; Kimball 1960; Green and Boardsen 2006; Farrona et al. 2011; Hayakawa et al. 2016, 2018b, 2019b; González-Esparza and Cuevas-Cardona 2018), February 1872 (Meldrun 1872; Silverman 2008; Hayakawa et al. 2018a), and May 1921 (Silverman and Cliver 2001; Love et al. 2019a, b), cause extremely intense magnetic storms. Among other effects, one of the most interesting visual phenomena is the occurrence of very intense and bright aurorae. Aurorae during extreme events are not only observed at high latitudes, but at low latitudes $\left(22-23^{\circ}\right)$ as well (Kimball 1960; Silverman 1995; Green and Boardsen 2006; Humble 2006; Silverman 2008; Cárdenas et al. 2016; Hayakawa et al. 2016; González-Esparza and Cuevas-Cardona 2018; Hayakawa et al. 2018b, 2019b).

\footnotetext{
*Correspondence: denny.m.deoliveira@nasa.gov; denny@umbc.edu ${ }^{1}$ Goddard Planetary Heliophysics Institute, University of Maryland, Baltimore County, Baltimore, MD, USA

Full list of author information is available at the end of the article
}

As such, mid- and low-latitude aurorae have formed footprints of major magnetic storms and hence major geo-effective solar eruptions (Vallance Jones 1992; Shiokawa et al. 2005; Silverman 2006; Willis et al. 2006, 2009; Schlegel and Schlegel 2011). Therefore, such auroral reports have been one of the key pathways to understand solar-terrestrial interactions in the past in terms of their long-term variability and cyclicity (Silverman 1992; Usoskin et al. 2013, 2015; Lockwood and Barnard, 2015; Lockwood et al. 2016; Vázquez et al. 2016; DomínguezCastro et al. 2016).

However, auroral phenomena have been rarely seen at low latitudes during moderate and even quiet magnetic conditions. Such events are known as sporadic aurorae (Silverman 2003). Botley (1963) introduced this term to the scientific community, citing previous descriptive usages of the same word by Abbe (1895). She introduced nine cases of low-latitude aurorae in Europe and in the Middle East observed in the twelfth and nineteenth centuries. Botley (1963) was the first to clearly define sporadic aurorae as "comprise such instances as a single ray in a sky otherwise seemingly clear of auroral light, or isolated patches well to the equatorial side

\section{Springer Open}

(c) The Author(s) 2020. This article is licensed under a Creative Commons Attribution 4.0 International License, which permits use, sharing, adaptation, distribution and reproduction in any medium or format, as long as you give appropriate credit to the original author(s) and the source, provide a link to the Creative Commons licence, and indicate if changes were made. The images or other third party material in this article are included in the article's Creative Commons licence, unless indicated otherwise in a credit line to the material. If material is not included in the article's Creative Commons licence and your intended use is not permitted by statutory regulation or exceeds the permitted use, you will need to obtain permission directly from the copyright holder. To view a copy of this licence, visit http://creativeco mmons.org/licenses/by/4.0/. 
of a great display". Botley (1963) also noted references to reports of two low-latitude aurora occurrences without the occurrence of high-latitude aurorae (Fritz 1881; Eddie 1894).

It took another four decades for the next paper on sporadic aurora to be published. Silverman (2003) provided a survey of considerable sporadic aurora observations in low-latitude regions of the United States during a time span of over half a century, and highlighted the occurrence of sporadic aurorae in the context of mid- to low-latitude aurorae during moderate-to-low magnetic activity. That paper was later followed by other papers with reports on sporadic aurora sightings from Iberia and the Canary Islands (Vaquero et al. 2007; Vázquez and Vaquero 2010), East Asia (Willis et al. 2007), Mexico (Vaquero et al. 2013), and the Philippines (Hayakawa et al. 2018c). Interestingly, Shiokawa et al. (2005) reported three cases of instrumental observations of mid-latitude aurora in Hokkaido (Japan) under fairly moderate magnetic activity as well.

Silverman (2003) speculated that sporadic aurorae may be caused by localized and ephemeral magnetospheric energy input into the low-latitude ionosphere, but he does not clearly suggest any physical mechanisms that may explain this phenomenon. In fact, considering the known correlation between intensity of magnetic disturbance and equatorward boundary of auroral ovals (Yokoyama et al. 1998), Silverman (2003)'s comprehensive survey was striking and casted an open question on its physical mechanism. Hayakawa et al. (2018c) suggested that at least part of sporadic aurorae might have been caused by the impact of inclined interplanetary shocks (see also Oliveira et al. 2018; Oliveira and Samsonov 2018) that strike the magnetosphere in the pre-dusk sector. However, despite all these efforts, a comprehensive understanding of the causes of sporadic aurorae still remains an open question in space weather research.

The main goal of this article is to show an aurora observation report published in a Rio de Janeiro's newspaper on 17 February 1875, hitherto unknown to the scientific community. Based on the event descriptions, the expertise of the observer, and the sporadic aurora characteristics presented in this introduction, as well as the magnetic latitude location of Rio de Janeiro and the low magnetic activity on the days before the observation, we will show that the event was most likely a sporadic aurora. The paper is structured as follows. "The observational site and the observer" section brings brief descriptions of the observational site and the observer. "The report and its interpretation" section introduces the report along with its interpretation based on current aurora knowledge. Finally, the paper is concluded in "Conclusion and a final remark" along with a final remark.

\section{The observational site and the observer The imperial observatory}

Brazil was a Portuguese colony during the period 1500 to 1822. Due to military and commercial sanctions imposed by Napoleon to Lisbon in the beginning of the nineteenth century, the throne of the Portuguese Empire exiled from Lisbon to Rio de Janeiro in 1808 (Fausto 1994). Later, John VI of Portugal returned back to Lisbon and left his son Peter I as the ruler of the Kingdom of Brazil. Then, on 7 September 1822, Peter I proclaimed Brazil's independence of Portugal, and became the first emperor of Brazil (Fausto 1994). In 1827, 7 years before his death, Peter I founded the Imperial Observatory (Morize 1987), today known as the National Observatory (Observatório Nacional), still located in Rio de Janeiro. After Peter I's death, his son Peter II became the second and last emperor of Brazil, when it became a Republic on 15 November 1889 (Fausto 1994). Peter II was a monarch very interested in science who supported many contemporary scientists, and used the auspices of the Imperial Observatory for astronomical observations and scientific discussions (Benevides 1979).

\section{Emmanuel Liais}

The likely sporadic aurora reported here was observed from the facilities of the Imperial Observatory by the Frenchman Emanuel Liais (1828-1900) on 15 February 1875. Liais was the director of the Imperial Observatory in 1875 , having been directly appointed by Peter II, after leaving the position as the director-adjunct of the Paris Observatory in France (Morize 1987). The observer was a professional nineteenth century scientist. While at the Imperial Observatory, Liais conducted research on astronomy with emphasis on planetary motion and comets, discovering one himself in 1860 (Liais 1860), he also published a popular book on astronomy (Liais 1865). Liais had considerable experience and expertise with optical physics and instrumentation. He published on the 1858 total solar eclipse observation from Brazil, being among the first to photograph the solar corona (Liais 1861; Aubin 2016), and apparently had a good understanding of atmospheric effects with respect to their altitude occurrences (Liais 1859; Muniz Barreto 1997). Liais also published on aurora observations from his home town Cherburg, France, on the Halloween day of 1853 (Liais 1853). More surprisingly, Liais even suggested methods to measure auroral altitudes, showing that aurorae occur far higher than meteorological phenomena (Liais 1851), as is well known today (e.g., Roach et al. 1960). According to Muniz Barreto (1997), these findings 
would have contributed to classify auroral phenomena as magnetic phenomena as opposed to meteorological phenomena if they had been published in a scientific journal with higher audience.

\section{The report and its interpretation}

\section{Presentation of the report}

Emmanuel Liais observed the aurora event on 15 February 1875 from Rio de Janeiro, Brazil. At that time, the Imperial Observatory was hosted by the Morro do Castelo (Castle Hill), an old church whose geographic coordinates are $22.75^{\circ} \mathrm{S}, 43.10^{\circ} \mathrm{W}$. Liais took notes of his observations and wrote a report to the local Jornal do Commercio (1875, Commerce Newspaper). This report was found in the data base of the National Digital Library of the National Library of Brazil (http://bndigital.bn.gov. br), hereafter BNDigital). We transcribed the full text of early modern Portuguese with its original spelling and grammar style in Appendix A: A1 and translated it into English in Appendix A: A2.

The observer noted the occurrence of the aurora by 19:45 local mean time (LMT), or 16:45 GMT (Greenwich Mean Time). He realized the presence of white light in the sky that was aligned with the terrestrial magnetic field. Later, he noted that the light rays, with variable intensities, moved from west to east and took some reddish color at the bottom and greenish color at the top. This display lasted for approximately $40 \mathrm{~min}$.

While we certainly need to be careful for possible misinterpretation of atmospheric optics as aurorae (e.g., Usoskin et al. 2017; Stephenson et al. 2019), there are three more descriptions that strongly suggest that the phenomenon observed by Liais was a sporadic aurora. First, he mentions that some clouds later passed below the auroral rays. Since Liais knew that the aurora is formed above meteorological phenomena occurring in the troposphere (Liais 1859; Muniz Barreto 1997) based on his previous experience with aurora observations (Liais 1853, 1859, 1865), here it seems that he was very convinced the lights he observed were indeed auroral lights rather than meteorological phenomena associated with clouds. Secondly, its reported direction and coloration seem to rule out this kind of possible contamination. This phenomenon appeared from the direction of the magnetic needle inclination and generated white stripes in a meridian direction. This is consistent and typical with auroral ray structure, extending along the magnetic field line (e.g., Chamberlain 1961). This phenomenon shows reddish color and faint greenish color well after sunset (18:40 LMT), whereas the nighttime atmospheric optics caused by the Moon is too faint to obtain its color detected by human eyes (Minnaert 1993).
Even more decisively, Liais saw this phenomenon with his spectroscope and confirmed "the certain evidence of proper lights". Spectroscopic observations frequently give us incontrovertible evidence to distinguish aurora from other atmospheric optics, as auroral spectra show emission lines, whereas spectra of solar reflected lights show absorption lines (see Fig. 1; e.g., Capron 1879, 1883; see also Love 2018; Stephenson et al. 2019). Therefore, we can incontrovertibly reject possible contamination of atmospheric optics or clouds with strange color.

Strangely, Liais interpreted the observed spectra as those of sulfur. This contradicts the modern understanding of auroral spectra as the present day understanding of the aurora shows that there are emissions mainly from oxygen and nitrogen (e.g., Gault et al. 1981; Chamberlain 1961). However, it is not Liais' originality to associate auroral spectra with sulfur. Back in mid eighteenth century, van Musschenbroek (1762) suggested aurorae were partially caused by burning sulfur. Liais performed his observations with a spectroscope only 6 years after the earliest spectroscopic observations of the aurora (Ångström 1869). Even in the 1870s, Capron (1879) acknowledged this early hypothesis of "sulfurous vapors issuing from the earth" as a cause of the aurora, while Capron

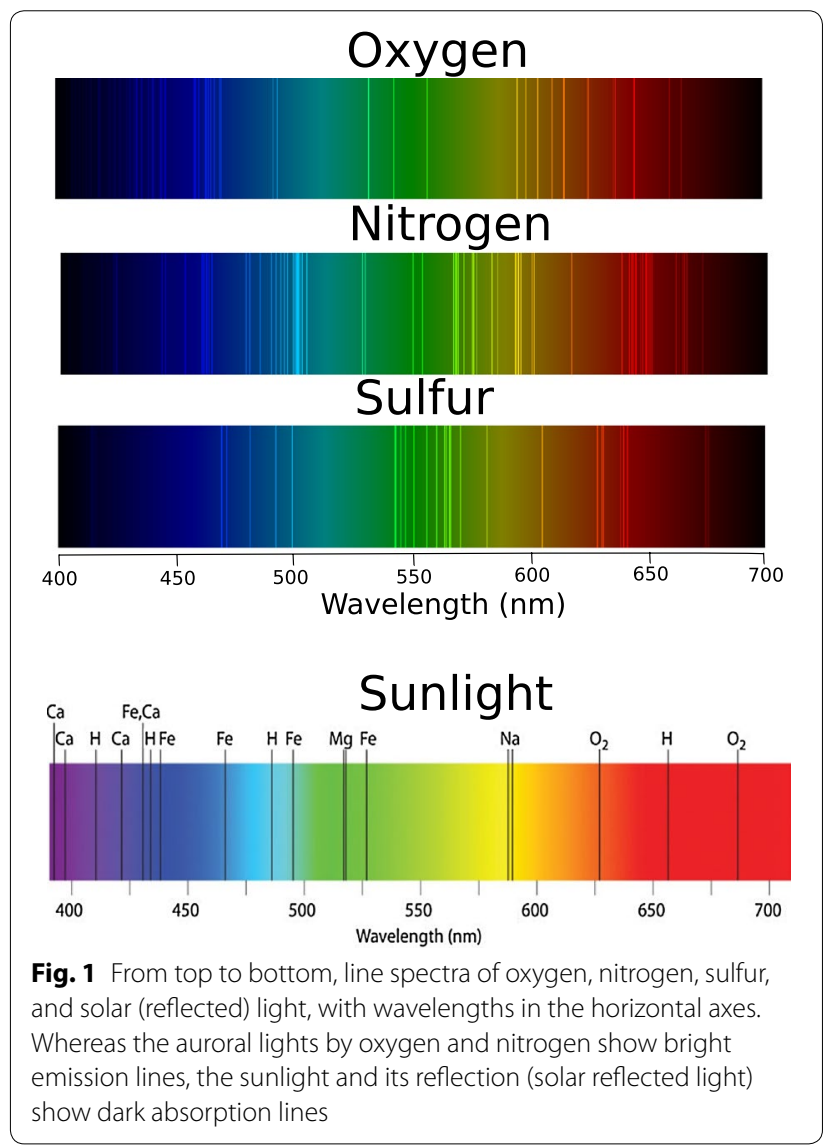


himself did not seem to agree with this supposed cause. Moreover, this misinterpretation may be justified by the similarity of spectra of sulfur emissions with spectra of mixed emissions of oxygen and nitrogen, as shown in Fig. 1. Since spectrum lines are considered a "fingerprint" of a source or object, this is a very important observation to distinguish aurorae form other optical phenomena. Therefore, most likely Liais was influenced by such early scientific discussions and misinterpreted the compound spectra of excited nitrogen and oxygen emissions as the emission spectrum of sulfur, as is understandable from the comparison of their spectra in Fig. 1.

Unlike aurorae, atmospheric optics or clouds cannot shine by themselves. The light source for clouds is sunshine or solar reflected light, including moonlight (e.g., Capron 1883; Love 2018; Stephenson et al. 2019). Therefore, as opposed to auroral emissions, the spectra of such atmospheric optics must inevitably involve dark absorption lines, typical with the sunlight (see Fig. 1; e.g., Capron 1879). As Liais saw this phenomenon with a spectroscope and associated it with aurora, we cannot associate this phenomenon with atmospheric optics, originated from the sunshine or solar reflected lights.

\section{Modern interpretation of the report}

There are only a few magnetic field observations that were regularly recorded around the world during the nineteenth century. The only magnetic indices that can be used for that period are the ak index (Nevanlinna 2004) and the aa index (Mayaud 1972). Unfortunately, there is no ak index for that date, but there is aa index for that date. The aa index is a 3-h time resolution magnetic index derived from two magnetic observatories in England and Australia that are nearly antipodal to each other (Mayaud 1972). The Aa index is then derived from the aa index by taking its daily averages. More detail of these indices can be found in the literature (Rostoker 1972; Mayaud 1980). The aa and Aa indices are provided by the British Geological Survey website.

Magnetic latitudes are computed by the geomagnetic field GUFM1 model (Jackson et al. 2000) from 1600 to 1990. This model is complimentary to the International Geomagnetic Reference Field (IGRF) model (Thèbault et al. 2015). IGRF can compute magnetic fields from 1900 onwards, but GUFM1 can compute magnetic fields as far back as 1590 due to the compilation of a massive data base obtained from observational logs compiled on ships at sea and ports around the world (Jackson et al. 2000; Jonkers et al. 2003).

The solid orange line in Fig. 2 shows the time evolution of Rio de Janeiro's magnetic latitude (MLAT) from 1600 to 1990 . The model shows that MLAT increased from $-18.4^{\circ}$ in 1600 to its maximum value (the closest value

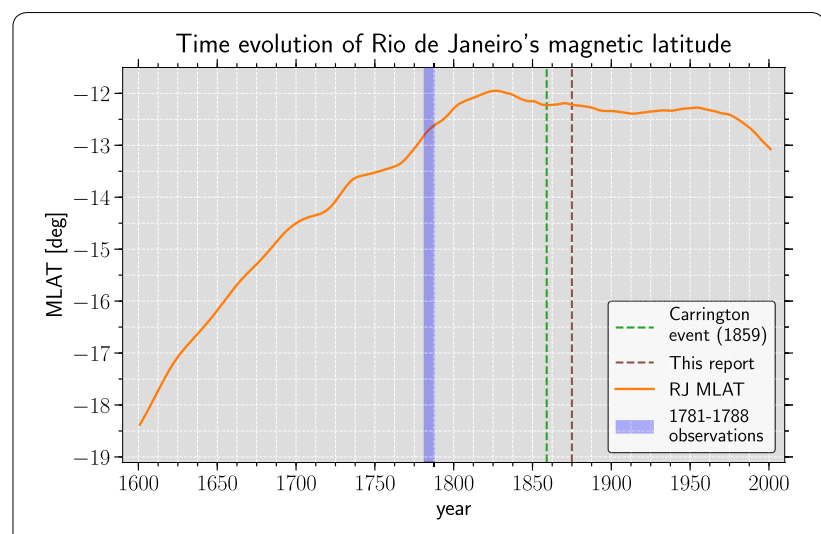

Fig. 2 Time evolution of Rio de Janeiro's magnetic latitude computed with the geomagnetic field model GUFM1 (Jackson et al. 2000). The light purple bar shows the period corresponding to Sanches Dorta's magnetic and aurora observations in Rio de Janeiro during the period 1781-1788 (Vaquero and Trigo 2005, 2006). The green and brown vertical lines mark the Carrington event (e.g., Green and Boardsen 2006; Hayakawa et al. 2018b, 2019b) and the eventual sporadic aurora observation here reported

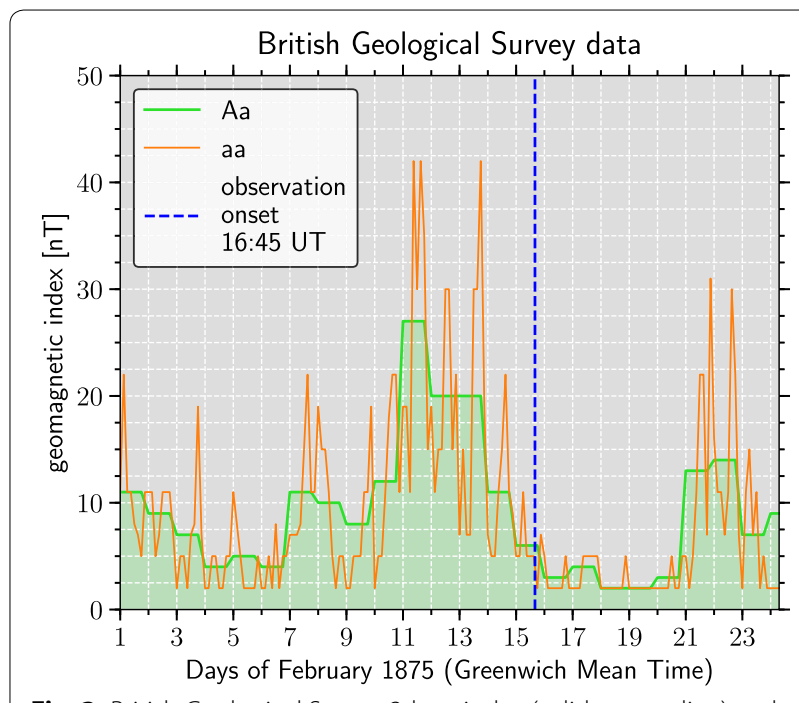

Fig. 3 British Geological Survey 3-h aa index (solid orange line) and the 24-h Aa index (solid green line/shaded green area) for the interval 1-24 February 1875. The dashed blue line indicates the onset of the aurora observation (15 February 1875 at 19:45 LMT/16:45 GMT) reported by Emmanuel Liais to the Jornal do Commercio (1875)

to the magnetic equator) slightly above $-12^{\circ}$ around 1816 when it started to decrease again. The highlighted light purple area (discussed later) corresponds to the 1781-1788 interval between aurorae observed from Rio de Janeiro. The dashed green vertical line marks the Carrington event occurrence (1859), while the dashed brown vertical line indicates the event reported in this letter (1875). 
Figure 3 shows the aa index for the interval 1-24 February 1875 . The solid orange line indicates 3 -h aa index (in $\mathrm{nT}$ ), while the shaded green line indicates the daily averaged Aa index. The dashed blue line corresponds to the beginning of Liais' observations (19:45 LMT or 1645 UT) reported to the Jornal do Commercio (1875). The plot documents that the $\mathrm{A}(\mathrm{a}) \mathrm{a}$ indices showed some weak/ mild activity 2-4 days prior to the aurora observation, with maximum Aa around $27 \mathrm{nT}$. This magnetic activity is consistent with sunspot number observations recorded a few days before, with very low values and one day with the observation number of 60 (Clette et al. 2014; Clette and Lefèvre 2016). The low magnetic activity conditions during that sporadic aurora event are consistent with the description suggested by Silverman (2003).

Additionally, the results of this study may also explain the reason why great aurora displays observed from Brazil have not been found/reported in the contemporary records for the Carrington event yet. As seen in Fig. 2, Rio de Janeiro's MLAT by 1859 was very low, around $-12.2^{\circ}$. While we surveyed auroral reports in Brazilian newspapers during the Carrington event in the BNDigital database, we found only references to great aurora displays and even telegraph system failures in North America and Europe, with nothing being reported as having been observed from Brazil.

Since the equatorward boundary of the auroral oval is reconstructed $\sim 28.5-30.4^{\circ}$ MLAT (Hayakawa et al. 2018b) assuming aurora height $\sim 400 \mathrm{~km}$ (Roach et al. 1960; Ebihara et al. 2017), the expected elevation of auroral visibility would be at best $3^{\circ}$ above the horizon and hence it was quite difficult to observe auroral displays in the sky of Rio de Janeiro (and other Brazilian locations) during the Carrington event. However, it would be worth surveying potential auroral reports in Argentine, Chile, and Uruguay, countries that are located in regions of higher MLATs in South America. Another significant event, the magnetic storm of 4 February 1872, also triggered great aurora displays at low latitudes (Silverman 2008; Hayakawa et al. 2018a). Silverman (2008) reported on possible aurora sightings in latitudes as low as $10^{\circ}$ or even $3^{\circ}$, while he casted a caveat on their reliability. The author reported aurora sightings on the French Reunion Island, in the Indian Ocean $\left(21.12^{\circ} \mathrm{S}, 55.54^{\circ} \mathrm{E}\right)$. We found mention to these aurora sightings during that storm in Brazilian newspapers while searching the BNDigital database, but none occurring from Rio de Janeiro or anywhere else in Brazil.

Another possibility is to interpret Liais' optical observations as equatorial plasma bubbles (EPBs), which are structures with depleted plasma density usually formed after sunset in the bottomside ionosphere and move from west to east (Mendillo and Tyler 1983; Kelley 2009; Liu et al. 2017). Since plasma bubbles are faint structures that can be hardly seen by the naked eye (e.g., Wiens et al. 2006), Liais' event most likely cannot be classified as an EPB event.

It should be mentioned that this is not the first report of an aurora observation performed from Rio de Janeiro, despite its proximity to the magnetic equator. In fact, Vaquero and Trigo $(2005,2006)$ and Carrasco et al. (2017) presented a series of magnetic observations and aurora sightings conducted by the Portuguese astronomer Sanches Dorta in the eighteenth century. According to the authors, the observations conducted by Sanches Dorta, during the period 1781 to 1788 , must very likely have occurred during times of elevated magnetic activity. However, according to Fig. 2, the MLATs of Rio de Janeiro during these events were around $-12.5^{\circ}$ (highlighted purple area). If the events reported by Vaquero and Trigo $(2005,2006)$ and Carrasco et al. (2017) were in fact caused by great magnetic storms, their visibility would have reached MLATs closer to the magnetic equator in comparison to the low-latitude Carrington aurorae previously reported (Green and Boardsen 2006; Hayakawa et al. 2018b, 2019a, b).

\section{Conclusion and a final remark}

Sporadic aurorae occur at low-latitude areas (Abbe 1895; Botley 1963) during moderate-to-low magnetic or even quiet conditions (Silverman 2003). However, despite being impressive, this space weather phenomenon is not very well known by the community. In addition, this phenomenon does not happen very often, and there are only a few publications reporting on sporadic aurora sightings (Abbe 1895; Boyer 1898; Botley 1963; Silverman 2003; Vaquero et al. 2007, 2013; Vázquez and Vaquero 2010; Willis et al. 2007; Hayakawa et al. 2018c).

In this letter, we presented for the first time a report on a possible sporadic aurora observation performed from Rio de Janeiro, Brazil, on 15 February 1875. This is the first sporadic aurora report in South America, and the second one in the southern hemisphere (the first observation was reported by Eddie 1894). Additionally, this is the second sporadic aurora observed near the magnetic equator. The original report was authored by Emmanuel Liais, then director of the Imperial Observatory of Rio de Janeiro, and published in the Jornal do Commercio (1875) of the same city. Given the scientific expertise, the contents of scientific descriptions and the experience of the observer, particularly with respect to the use of a spectroscope, Liais' report may be considered credible and possible misinterpretation of the observed phenomenon, such as caused by atmospheric optics (Usoskin et al. 2017; Hayakawa et al. 2018c), may be discarded. The aurora description presented by Liais is consistent with 
sporadic aurorae (Abbe 1895; Botley 1963; Silverman 2003). In addition, the very low magnetic latitude of Rio de Janeiro and the weak/mild magnetic activity during the observations are consistent with a previous sporadic aurora observation near the magnetic equator (Hayakawa et al. 2018c).

Furthermore, in addition to the sporadic aurora causes presented in the introductory section, we speculate that sporadic aurorae may also be caused by the flow of solar wind phase fronts with some inclination in the equatorial plane toward the dusk flank. As suggested by Cameron et al. (2019), such flows of solar wind phase fronts during times of low magnetic activity or quiet conditions would increase magnetic activity over time due to shear and viscosity effects, and the sudden release of this energy may cause sporadic aurorae. More observations and possibly numerical simulations are needed in order to test these hypotheses and advance the knowledge of sporadic aurora triggering.

\section{Abbreviations \\ MLAT: Magnetic latitude; LMT: Local mean time; GMT: Greenwich mean time; BNDigital: Digital Library of the National Library of Brazil; IGRF: International Geomagnetic Reference Field; EPB: Equatorial plasma bubble.}

\section{Acknowledgements}

The authors thank the National Library of Brazil (Biblioteca Nacional do Brasil) for providing and keeping a public newspaper archive (http://www.bn.br). The authors also acknowledge the British Geological Survey for providing the magnetic index data used in this investigation and Yusuke Ebihara for his helpful comments. Finally, we thank Martin Rehfeld for providing and making a FORTRAN code version of the GUFM1 model public at his web-service hosting GitHub website (https://github.com/martinrehfeld).

\section{Authors' contributions}

$\mathrm{DMO}$, who is proficient in Portuguese, surveyed the BNDigital database to search for historical accounts of auroral observations from Brazil. He also used GUFM1 to compute magnetic fields and coordinates. $\mathrm{HH}$ provided background of space weather events in history particularly with respect to sporadic aurorae. EZ contributed with the interpretation of the historical data and observations in the light of current auroral scientific understanding. $A B$ contributed with interpreting spectroscopic observations. GV provided fundamental information on the ionospheric and magnetic field variations at low latitudes. All authors read and approved the final manuscript.

\section{Funding}

DMO thanks the financial support of the NASA grants 13-SRITM132-0011 and HSR-MAG142-0062, under contract with UMBC. HH acknowledges the JSPS Grand-in-Aid grant JP17J06954, JP15H05816, JP15H05812, and JP15K21709. AB acknowledges the support by the NASA Living With a Star Jack Eddy Postdoctoral Fellowship Program, administered by the Catholic University of America.

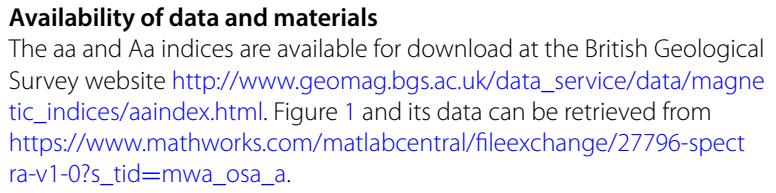

Ethics approval and consent to participate Not applicable.
Consent for publication

Not applicable.

Competing interests

The authors declare that they have no competing interests.

\begin{abstract}
Author details
${ }^{1}$ Goddard Planetary Heliophysics Institute, University of Maryland, Baltimore County, Baltimore, MD, USA. ${ }^{2}$ NASA Goddard Space Flight Center, Greenbelt, MD, USA. ${ }^{3}$ Institute for Space-Earth Environmental Research, Nagoya University, Nagoya, Japan. ${ }^{4}$ Institute for Advanced Researches, Nagoya University, Nagoya 4648601, Japan. ${ }^{5}$ Rutherford Appleton Laboratory, Chilton, UK. ${ }^{6}$ Catholic University of America, Washington, DC, USA. ${ }^{7}$ Indian Institute of Geomagnetism, Plot 5, Sector 18, New Panvel (West), Navi Mumbai, India.
\end{abstract}

\section{Appendix A: The report \\ A1 Original transcript written in old Portuguese}

Rio de Janeiro, 17 de fevereiro de 1875

Jornal do Commercio

Aurora austral: O Sr. Emmanuel Liais, director do observatorio astronomico do Rio de Janeiro, enviou-nos ontem as sequintes observações que fez sobre a aurora austral, de que já démos resumida notícia:

A's $73 / 4$ da noite foi a minha atenção despertada por uma especie de véo espalhado sobre todo o céo formando uma serie de listras esbranquiçadas, que começavam ao sul sobre um arco de circulo, cujo centro achava-se abaixo do horisonte, na direção da agulha magnetica de inclinação. As listras ou raios eram de tal extensão que atravessavam o céo do sul ao norte, onde convergiam para o ponto diametralmente oposto.

Esta disposição, reproduzindo a forma das auroras boreaes, fez-me desde logo suppôr que bem podia ser uma aurora austral o phenomeno que presenciava; infelizmente não podia affirmal-o por causa da presença da lua momentos depois, porém, fiquei inteiramente convencido disso, graças a outras circumstancias que o acompanháram.

Com effeito, depois de cinco minutos de observação, passaram de oéste para léste, e duas vezes manifestaramse variações successivas de intensidade nos raios, como se dá frequentemente nas auroras boreaes e austraes. Além disso, passados mais alguns minutos os raios, cujas intensidades haviam augmentado, tomaram na parte inferior uma tenue côr avermelhada e na superior verde desmaiada, que não podia ser effeito da luz reflectida da lua.

Observei então com o espectroscopio, onde appareciam linhas brilhantes, indicio certo de luzes proprias. Todas elas pertenciam ao enxofre, substancia que, como é sabido, encontra-se em quantidade apreciavel na atmosphera.

Em seguida olhei para o norte, onde vi dous relampagos, e notei que se formavam pequenas nuvens de uma fórma variavel pelo effeito de condensação e da 
dissolução de vapores. Muitas nuvens caminhavam na direção de léste, um pouco ao sul, passando abaixo dos raios da aurora; ao mesmo tempo estes diminuiam de intensidade e as côres da parte inferior tinham desapparecido.

Observei mais um halo fraco em volta da lua, dentro de um tenue véo de vapor, e como já o assignalou por Bravais, este halo era um tanto mais forte nas intercepções com os raios da aurora. Pouco depois estes raios começaram a encurtar e a retirar-se para o Sul.

Foi então que deixando a observação ás 8 horas e 20 minutos, mandei para o Lornal a noticia deste phenomeno. Quando tornei a subir ao terraço os numerosos raios existiam ainda, porem mais curtos e mais fracos. Pelas 8 horas e 40 minutos começaram a desapparecer, e ás 9 horas só se vião pequenos vestigios delles junto ao horisonte, de léste a oeste particularmente.

A's 10 horas parecia quererem formar-se outra vez dous ou tres raios, mas desappareceram pouco depois, e pequenas nuvens condensaram-se sobre diversos pontos do céo. Nada mais aconteceu até às 3 horas da madrugada, occasião em que fui chamado para vêr dous raios brilhantes que tinham reapparecido a leste, e que por causa da ausencia da luz lunar, chammavam mais a attenção.

Depois de diminuirem, reapparecêram quatro raios na mesma região, mais fracos, porém, do que os primeiros, e duraram até que a luz do dia nascente veio fazer cessar de todo o phenomeno, e ao amanhecer o céo mostrou-se coberto de tenues cirrus.

São estes os pormenores da observação, cujas deducções farão o objeto de uma memoria especial.

\section{A2 Translation of the original transcript into modern English \\ Rio de Janeiro, February 17, 1875 \\ Commerce Newspaper}

Aurora australis-Mr. Emmanuel Liais, director of the astronomical observatory of Rio de Janeiro, sent us yesterday the following observations that he made on the aurora australis, on which we already reported:

At 7:45 p.m. my attention was caught by a kind of bridal veil spread all over the sky forming a series of white stripes that started in the south on a circular arc whose center was below the horizon, in the direction of the magnetic needle inclination. The stripes or rays were of such an extension that they passed through the sky from south to north, where they converged at the diametrically opposite point.

Such disposition, producing the form of aurora borealis, made me suppose at once that it could be an aurora australis the phenomenon I witnessed; unfortunately I could not affirm that because of the Moon's presence: moments later, however, I was entirely convinced that was the case, thanks to other circumstances that accompanied it.

In fact, after 5 min of observation, they passed from west to east, and twice successive appearances with a variety of ray intensities occurred, as often happens with aurora borealis and australis. In addition, after a few more minutes the rays, whose intensity had augmented, took in their inferior part a reddish color and in their superior part a faint greenish color that could not result from the effect of the light reflected by the Moon.

I observed then with a spectroscope, where bright lights appeared, the certain evidence of proper lights. All lights belonged to sulfur, a substance that, as is well known, is found in large amounts in the atmosphere.

Then I looked towards the north, where I saw two light bolts, and noticed that small clouds formed in a variable form by effects of condensation and dissolution of vapors. Such clouds moved towards the east direction, slightly to the south, passing below the aurora rays; at the same time the rays decreased in intensity and the colors of the inferior part had disappeared.

I observed one more weak halo around the Moon inside a thin veil of vapor, and as pointed out by Bravais, such halo was somewhat stronger in the interceptions with the aurora rays. Later such rays started to get shorter and move southward.

Then when I left the observation at 8:20 p.m. I sent to the Newspaper the news of this phenomenon. When I went back up to the terrace the numerous rays still existed, however they were shorter and weaker. Around 8:40 p.m. they began to disappear, and at 9:00 p.m. it was possible to see only their vestiges together in the horizon, particularly from east to west.

At 10:00 p.m. two or three rays appeared to be formed once more, but they disappeared later, and small clouds condensed over several points in the sky. Nothing more took place until 3:00 a.m., occasion on which I was called to see two very bright rays that had reappeared towards the east, which caught more attention because of the absence of lunar light.

After diminishing, four rays appeared in the same region, however, weaker in comparison to the first ones, and lasted until the light of the breaking day brought the phenomenon to an end, and at dawn it was shown that the sky was covered by a faint cirrus.

These are the details of the observations, whose deductions will make an object of a special memory.

Received: 23 April 2020 Accepted: 24 May 2020

Published online: 06 June 2020 


\section{References}

Abbe C (1895) An aurora in South Carolina and Kentucky. Mon Weather Rev 23(8):297-298. https://doi.org/10.1175/1520-0493(1895)23\%5b297:aaisc a\%5d2.0.co;2

Ångström JA (1869) On the Spectrum of the Aurora Borealis. Lond Edinb Dublin Philos Mag J Sci 38(244):246-247. https://doi. org/10.1080/14786446908640219

Aubin D (2016) Liais, Emmanuel-Benjamin. In: Hockey T (ed) Biographical encyclopedia of astronomers. Springer, Dordrecht, pp 1320-1321. https://doi.org/10.1007/978-1-4419-9917-7_847

Benevides JMA (1979) D. Pedro II, o patrono da astronomia brasileira. Imprensa Oficial do Ceará, Fortaleza

Botley CM (1963) Sporadic aurora. Planet Space Sci 11(6):723-724. https:// doi.org/10.1016/0032-0633(63)90176-4

Boyer HB (1898) Anomalous and Sporadic Auroras. Mon Weather Rev 26(5):260-261 https://doi.org/10.1175/1520-0493(1898)26[260:aasa]2 .0.CO;2

Cameron TG, Jackel BJ, Oliveira DM (2019) Using mutual information to investigate geoeffectiveness of solar wind phase fronts with different front orientations. J Geophys Res Space Phys 124(3):1582-1592. https ://doi.org/10.1029/2018JA026080

Capron JR (1879) Aurorae: their characters and spectra. London, E. \& F. N. Spon, London

Capron JR (1883) XLVII. The auroral beam of November 17, 1882. Lond Edinb Dublin Philos Mag J Sci 15(95):318-339. https://doi.org/10.1080/14786 448308627358

Cárdenas FM, Sanchez SC, Dominguez SV (2016) The grand aurorae borealis seen in Colombia in 1859. Adv Space Res 57(1):257-267. https://doi. org/10.1016/j.asr.2015.08.026

Carrasco VMS, Trigo RM, Vaquero JM (2017) Unusual rainbows as auroral candidates: another point of view. Publ Astron Soc Jpn 69:L1. https:// doi.org/10.1093/pasj/psw127

Carrington RC (1859) Description of a singular appearance seen in the Sun on September 1, 1859. Mon Notes R Astron Soc 20(1):13-15. https:// doi.org/10.1093/mnras/20.1.13

Chamberlain JW (ed) (1961) Physics of the aurora and airglow, geophysical monograph series, vol 41. American Geophysical Union, Washington. https://doi.org/10.1029/sp041

Clette F, Lefèvre L (2016) The new sunspot number: assembling all corrections. Sol Phys 291(9-10):2629-2651. https://doi.org/10.1007/s1120 7-016-1014-y

Clette F, Svalgaard L, Vaquero JM, Cliver EW (2014) Revisiting the sunspot number. Space Sci Rev 184(1-4):35-103. https://doi.org/10.1007/s1121 4-014-0074-2

Domínguez-Castro F, Vaquero JM, Bertolin C, Gallego M-C, De la Guía C. Camuffo D (2016) Aurorae observed by Giuseppe Toaldo in Padua (1766-1797). J Space Weather Space Clim 6:A21. https://doi. org/10.1051/swsc/2016016

Ebihara Y, Hayakawa H, Iwahashi K, Tamazawa H, Kawamura AD, Isobe H (2017) Possible cause of extremely bright aurora witnessed in East Asia on 17 September 1770. Space Weather 15(10):1373-1382. https://doi org/10.1002/2017SW001693

Eddie LA (1894) Note on an auroral display. J Br Astron Assoc 4:381

Farrona AMM, Gallego MC, Vaquero JM, Domínguez-Castro F (2011) Spanish eyewitness accounts of the great space weather event of 1859. Acta Geodaetica et Geophysica Hungarica 46(3):370-377. https://doi. org/10.1556/ageod.46.2011.3.7

Fausto B (1994) História do Brasil. Edusp, São Paulo

Fritz H (1881) Das polarlicht. F. A. Brockhaus AG, Leipzih

Gault WA, Koehler RA, Link R, Shepherd GG (1981) Observations of the optical spectrum of the dayside magnetospheric cleft aurora. Planet Space Sci 29(3):321-333. https://doi.org/10.1016/0032-0633(81)90020-9

González-Esparza JA, Cuevas-Cardona MC (2018) Observations of lowlatitude red aurora in Mexico During the 1859 Carrington geomagnetic storm. Space Weather 16(6):593-600. https://doi.org/10.1029/2017S W001789

Green JL, Boardsen S (2006) Duration and extent of the great auroral storm of 1859. Adv Space Res 38(2):130-135. https://doi.org/10.1016/j. asr.2005.08.054

Hayakawa H, Iwahashi K, Tamazawa H, Isobe H, Kataoka R, Ebihara Y, Miyahara H, Kawamura AD, Shibata K (2016) East Asian observations of low-latitude aurora during the Carrington magnetic storm. Publ Astron Soc Jpn 68(6):1-13. https://doi.org/10.1093/pasj/psw097

Hayakawa H, Ebihara Y, Hand DP, Hayakawa S, Kumar S, Mukherjee S, Veenadhari B (2018a) Low-latitude aurorae during the extreme space weather events in 1859. Astrophys J 869(57):1-17. https://doi.org/10.3847/15384357/aae47c

Hayakawa H, Ebihara Y, Willis DM, Hattori K, Giunta AS, Wild MN, Hayakawa S, Toriumi S, Mitsuma Y, Macdonald LT, Shibata K, Silverman SM (2018b) The great space weather event during 1872 February recorded in East Asia. Astrophys J 862(15):1-10. https://doi.org/10.3847/1538-4357/aaca40

Hayakawa H, Vaquero JM, Ebihara Y (2018c) Sporadic auroras near the geomagnetic equator: in the Philippines, on 27 October 1856. Ann Geophys 36:1153-1160. https://doi.org/10.5194/angeo-36-1153-2018

Hayakawa H, Ebihara Y, Cliver EW, Hattori K, Toriumi S, Love JJ, Umemura N, Namekata K, Sakaue T, Takahashi T, Shibata K (2019a) The extreme space weather event in September 1909. Mon Notes R Astron Soc 484(3):40834099. https://doi.org/10.1093/mnras/sty3196

Hayakawa H, Ebihara Y, Willis DM, Toriumi S, lju T, Hattori K, Wild MN, Oliveira DM, Ermolli I, Ribeiro JR, Correia AP, Ribeiro Al, Knipp DJ (2019b) Temporal and spatial evolutions of a large sunspot group and great auroral storms around the Carrington event in 1859. Space Weather 17(11):1553-1569. https://doi.org/10.1029/2019SW002269

Humble JE (2006) The solar events of August/September 1859—surviving Australian observations. Adv Space Res 38(2):155-158. https://doi. org/10.1016/j.asr.2005.08.053

Jackson A, Jonkers ART, Walker MR (2000) Four centuries of geomagnetic secular variation from historical records. Philos Trans R Soc Ser A 358(1768):957-990. https://doi.org/10.1098/rsta.2000.0569

Jonkers ART, Jackson A, Murray A (2003) Four centuries of geomagnetic data from historical records. Rev Geophys. https://doi.org/10.1029/2002rg0001 15

Jornal do Commercio (1875) Published on 17 February 1875 by Julio Constancio de Villeneuve, pp 3. http://memoria.bn.br/DocReader/DocReader. aspx?bib =36456806\&pesq $=$ australis\&pasta $=$ ano\%20187. Accessed 30 May 2020

Kelley MC (2009) The earth's ionosphere. Academic Press, London

Kimball DS (1960) A study of the Aurora of 1859 (Tech. Rep. No. Scientific Report No 6). Fairbanks: Geophysical Institute, University of Alaska

Liais E (1851) Sur la hauteur des aurores boréales. Comptes rendus de I'Académie des Sciences 33:302-305

Liais E (1853) Observations sur une aurore boréale vue à Cherburg, le 31 Octobre 1853. Comptes rendus de l'Académie des Sciences 37:746-749

Liais $E$ (1859) Sur la hauteur de l'atmosphère déduite d'observations de polarisation fautes dans la zone intertropicale au commencement de l'aurore et `a la fin de crépuscule. Comptes rendus de l'Académie des Sciences 48:109-112

Liais E (1860) Sur la troisième comète de 1860, déscouverte à Olinda de 26 Février. Comptes rendus de l'Académie des Sciences 51:65-67

Liais E (1861) Détermination de la longitude de Paranagua au moyen d'préuves photographiques de l'éclipse du 7 Septembre 1858. Comptes rendus de l'Académie des Sciences 53:29-32

Liais E (1865) L'espace celeste et la nature tropicale: Description physique de I'univers. Garnier Fréres, Paris

Liu H, Pedatella N, Hocke K (2017) Medium-scale gravity wave activity in the bottomside F region in tropical regions. Geophys Res Lett 44(14):7099_ 7105. https://doi.org/10.1002/2017GL073855

Lockwood M, Barnard L (2015) An arch in the UK: a new catalogue of auroral observations made in the British Isles and Ireland. Astron Geophys 56:25-30. https://doi.org/10.1093/astrogeo/atv132

Lockwood M, Owens MJ, Barnard L, Scott CJ, Usoskin IG, Nevanlinna H (2016) Tests of sunspot number sequences: 2. Using Geomagn Auroral Data Solar Phys 291:2811-2828. https://doi.org/10.1007/s11207-016-0913-2

Love JJ (2018) The electric storm of November 1882. Space Weather 16(1):3746. https://doi.org/10.1002/2017SW001795

Love JJ, Hayakawa H, Cliver EW (2019a) On the intensity of the magnetic superstorm of September 1909. Space Weather 17(1):37-45. https://doi. org/10.1029/2018SW002079

Love JJ, Hayakawa H, Cliver EW (2019b) Intensity and impact of the New York Railroad superstorm of May 1921. Space Weather 17:1281-1292. https:// doi.org/10.1029/2019SW002250 
Mayaud P-N (1972) The aa indices: a 100-year series characterizing the magnetic activity. J Geophys Res 77(34):6870-6874. https://doi.org/10.1029/ JA077i034p06870

Mayaud PN (ed) (1980) Derivation, meaning and use of geomagnetic indices, geophysical monograph series, vol 22. American Geophysical Union, Washington. https://doi.org/10.1029/gm022

Meldrun J (1872) Aurora Australis. Nature 5:392-393. https://doi. org/10.1038/005392a0

Mendillo M, Tyler A (1983) Geometry of depleted plasma regions in the equatorial ionosphere. J Geophys Res 88(A7):5778-5782. https://doi. org/10.1029/JA088iA07p05778

Minnaert N (1993) Light and color in the outdoors. Springer, New York

Morize HC (1987) O observatório astronômico: um século de história 1827-1927. Melhoramentos, São Paulo

Muniz Barreto L (1997) El geomagnetismo. Plaza y Valdés, San Rafael

Nevanlinna H (2004) Results of the Helsinki magnetic observatory 18441912. Ann Geophys 21:1691-1704. https://doi.org/10.5194/angeo -22-1691-2004

Oliveira DM, Samsonov AA (2018) Geoeffectiveness of interplanetary shocks controlled by impact angles: a review. Adv Space Res 61(1):1-44. https:// doi.org/10.1016/j.asr.2017.10.006

Oliveira DM, Arel D, Raeder J, Zesta E, Ngwira CM, Carter BA, Yizengaw E, Halford AJ, Tsurutani BT, Gjerloev JW (2018) Geomagnetically induced currents caused by interplanetary shocks with different impact angles and speeds. Space Weather 16(6):636-647. https://doi.org/10.1029/2018S W001880

Roach FE, Moore JG, Bruner EC Jr, Cronin H, Silverman SM (1960) The height of maximum luminosity in an auroral arc. J Geophys Res 65(11):3575-3580. https://doi.org/10.1029/JZ065i011p03575

Rostoker G (1972) Geomagnetic indices. Rev Geophys 10(4):935-950. https:// doi.org/10.1029/RG010i004p00935

Schlegel B, Schlegel K (2011) Polarlichter zwischen Wunder und Wirklichkeit. Spektrum Akademischer Verlag, Heidelberg. https://doi. org/10.1007/978-3-8274-2881-3

Shiokawa K, Ogawa T, Kamide Y (2005) Low-latitude auroras observed in Japan: 1999-2004. J Geophys Res. https://doi.org/10.1029/2004ja010706

Silverman SM (1992) Secular variation of the aurora for the past 500 years. Rev Geophys 30:333-351. https://doi.org/10.1029/92RG01571

Silverman SM (1995) Low latitude auroras: the storm of 25 September 1909. J Atmos Solar Terr Phys 57(6):673-685. https://doi.org/10.1016/00219169(94)E0012-C

Silverman SM (2003) Sporadic auroras. J Geophys Res 108:A4. https://doi. org/10.1029/2002JA009335

Silverman SM (2006) Comparison of the aurora of September 1/2, 1859 with other great auroras. Adv Space Res 38:136-144. https://doi.org/10.1016/j. asr.2005.03.157

Silverman SM (2008) Low-latitude auroras: the great aurora of 4 February 1872. J Atmos Solar Terr Phys 70(10):1301-1308. https://doi.org/10.1016/j.jastp .2008.03.012

Silverman SM, Cliver EW (2001) Low-latitude auroras: the magnetic storm of 14-15 May 1921. J Atmos Solar Terr Phys 63:523-535. https://doi. org/10.1016/S1364-6826(00)00174-7

Stephenson FR, Willis DM, Hayakawa H, Ebihara Y, Scott CJ, Wilkinson J, Wild MN (2019) Do the Chinese Astronomical Records Dated AD 776 January 12/13 Describe an Auroral Display or a Lunar Halo? A critical re-examination. Solar Physics 294(4):1-24. https://doi.org/10.1007/s1120 7-019-1425-7
Thèbault E, Finlay CC, Beggan CD, Alken P, Aubert J, Barrois O et al (2015) International geomagnetic reference field: the 12th generation. Earth Planets Space 67(1):1-19. https://doi.org/10.1186/s40623-015-0228-9

Usoskin IG, Kromer B, Ludlow F, Beer J, Friedrich M, Kovaltsov GA, Solanki SK, Wacker L (2013) Astron Astrophys 552:L3. https://doi.org/10.1051/0004$6361 / 201321080$

Usoskin IG et al (2015) The Maunder minimum (1645-1715) was indeed a grand minimum: a reassessment of multiple datasets. Astron Astrophys 581:A95. https://doi.org/10.1051/0004-6361/201526652

Usoskin IG, Kovaltsov GA, Mishina LN, Sokoloff DD, Vaquero J (2017) An optical atmospheric phenomenon observed in 1670 over the City of Astrakhan Was Not a Mid-Latitude Aurora. Solar Phys. https://doi.org/10.1007/s1120 7-016-1035-6

Vallance Jones A (1992) Historical review of great auroras. Can J Phys 70:479487. https://doi.org/10.1139/p92-083

van Musschenbroek P (1762) Introductio ad philosophiam naturalem, Apud Sam. et Joh. Luchtmans, v.1, Leiden, The Netherlands

Vaquero JM, Trigo RM (2005) Results of the Rio de Janeiro magnetic observations 1781-1788. Ann Geophys 23:1881-1887. https://doi.org/10.5194/ angeo-23-1881-2005

Vaquero JM, Trigo RM (2006) Identification of possible intense historical solar storms during the years 1781-1788 Inferred from Aurorae and Geomagnetic Observations in Rio De Janeiro. Sol Phys 235(1-2):419-432. https:// doi.org/10.1007/s11207-006-0024-6

Vaquero JM, Trigo RM, Gallego MC (2007) Sporadic aurora from Spain. Earth Planets Space 59(11):e49-251. https://doi.org/10.1186/BF03352061

Vaquero JM, Gallego MC, Dominguez-Castro F (2013) A possible case of Sporadic Aurora in 1843 from Mexico. Geofísica Internacional 52(1):87-92. https://doi.org/10.1016/S0016-7169(13)71464-8

Vázquez M, Vaquero JM (2010) Aurorae Observed at the Canary Islands. Sol Phys 267(2):431-444. https://doi.org/10.1007/s11207-010-9650-0

Vázquez M, Vaquero JM, Gallego MC, Roca Cortés T, Pallé PL (2016) Long-term trends and Gleissberg cycles in aurora borealis records (1600-2015). Sol Phys 291:613-642. https://doi.org/10.1007/s11207-016-0849-6

Wiens RH, Ledvina BM, Kintner PM, Afewerki M, Mulugheta Z (2006) Equatorial plasma bubbles in the ionosphere over Eritrea: occurrence and drift speed. Ann Geophys 24(5):1443-1453. https://doi.org/10.5194/angeo -24-1443-2006

Willis DM, Henwood R, Stephenson FR (2006) The presence of large sunspots near the central solar meridian at the times of modern Japanese auroral observations. Ann Geophys 24:2743-2758. https://doi.org/10.5194/ angeo-24-2743-2006

Willis DM, Stephenson FR, Fang H (2007) Sporadic aurorae observed in East Asia. Ann Geophys 25:417-436. https://doi.org/10.5194/angeo $-25-417-2007$

Willis DM, Henwood R, Stephenson FR (2009) The presence of large sunspots near the central solar meridian at the times of major geomagnetic storms. Ann Geophys 27:185-197. https://doi.org/10.5194/angeo -27-185-2009

Yokoyama N, Kamide Y, Miyaoka H (1998) The size of the auroral belt during magnetic storms. Ann Geophys 16:566-573. https://doi.org/10.1007/ s00585-998-0566-Z

\section{Publisher's Note}

Springer Nature remains neutral with regard to jurisdictional claims in published maps and institutional affiliations. 